Journal of Agricultural Sciences
(Tarim Bilimleri Dergisi)

\title{
Hydrogeochemical Characteristics of Spring Waters for Irrigation, Gökpınar Basin Case, Denizli, Turkey
}

\author{
Suat TAŞDELENa ${ }^{\text {iD }}$ \\ ${ }^{a}$ Pamukkale University, Department of Geological Engineering, Denizli, TURKEY \\ ARTICLE INFO \\ Research Article \\ Corresponding Author: Suat TAŞDELEN, E-mail: stasdelen@pau.edu.tr \\ Received: 29 May 2020 / Revised: 24 July 2020 / Accepted: 14 September 2020 / Online: 04 December 2021
}

\section{ABSTRACT}

In this study, a detailed hydrochemical evaluation has been made to determine the chemical processes of spring waters and their suitability for irrigation. The study area consists of a drainage basin of the Gökpınar dam and has fertile soils for irrigable agriculture. During the period of August 2017 and October 2018, regular samples were collected monthly from 10 spring and 140 samples in total were subjected to hydrochemical analysis. For this purpose, 11 hydrochemical parameters such as $\mathrm{pH}, \mathrm{EC}$, TDS, TH, Na\%, SAR, MR, RSC, RSBC, USSL, and Wilcox were used. GIS-based spatial mapping of the hydrogeochemical parameters has been prepared using ArcGIS. The major hydrogeochemical facies of waters are
$\mathrm{Ca}^{2+}, \mathrm{Mg}^{2+}, \mathrm{HCO}_{3}{ }^{-}$water type. Alkaline earth metals $\left(\mathrm{Ca}^{2+}, \mathrm{Mg}^{2+}\right)$ and weak acid $\left(\mathrm{CO}_{3}{ }^{2-}, \mathrm{HCO}_{3}^{-}\right)$dominates over the alkalies $\left(\mathrm{Na}^{+}, \mathrm{K}^{+}\right)$and strong acid $\left(\mathrm{Cl}^{-}, \mathrm{SO}_{4}{ }^{2-}\right)$ in all spring waters, respectively. Since the limit values of TDS in the samples are between 367 and $681 \mathrm{mgL}^{-1}$, the class of all samples is freshwater. The average $\mathrm{Na} \%$ is between 1.29 and 9.28 , and $\mathrm{EC}$ values are between 402 and $691 \mu \mathrm{Scm}^{-1}$. For irrigation purposes, all spring waters fall within the category of "excellent to good" in the Wilcox (1955) diagram, based on the $\mathrm{Na} \%$ and EC. Average SAR values in the range of $0.07-0.16 \mathrm{meqL}^{-1}$ indicate that spring water samples are excellent for irrigation purposes.

Keywords: Agricultural areas, Water quality, Catchment, GIS mapping

(C) Ankara University, Faculty of Agriculture

\section{Introduction}

Water is the most valuable compound on the earth, essential for humans and all other living things. The chemical composition of groundwater and their suitability for different purposes vary according to different processes in their natural environment. Continuous monitoring of the quality of natural freshwater is important for human health, agricultural production, and soil fertility. Understanding the hydrogeochemical properties and evolution of spring waters in a basin can provide important knowledge for the future management of water resources in that region (Meybeck \& Helmer 1996; Kumar et al. 2009; Tiwari 2011). The dominant factors controlling the suitability of spring waters for irrigation are water chemistry, soil properties, salt sensitivity of plants, climate, and drainage (Appelo \& Postma 2005). Irrigation water quality has a direct impact on the structure of the soil, and hence on crop productivity and quality (Roy et al. 2015). The prevalence and diversity of anthropogenic activities limit the water quality in nature and disrupt the ecosystem. These processes are rock-water interaction, its mix with other water sources in different facies, human factors, etc (Andrade et al. 2008). There are numerous studies on spring water characteristics' evaluation using hydrochemical techniques all around the world (Ako et al. 2012; Bhandari and Joshi 2013; Dinka et al. 2015; Nair et al. 2015; Kamtchueng et al. 2016; Batool et al. 2018).

The aim of this study is to investigate the irrigation water characteristics of spring waters, which are one of the main components of the water body feeding the Gökpınar Dam. The spring waters in the basin are used by the local people as a primary water source for drinking and domestic use as well as agriculture. Although spring waters are considered reliable since they come from groundwater, their quality is actually based on certain physicochemical parameters (Edmunds \& Shand 2009). This study confirms that all spring water samples in the basin are suitable for irrigation, based on long-term physical parameters and chemical analysis results. Likewise, all springs are safe to use in terms of physical parameters, chemical composition, soil properties, salt sensitivity of plants, and drainage. During the study, the parameters controlling the chemical properties of the spring waters in the basin were analysed. The changes in the chemical properties of the spring waters in the study area are due to the rock-water interaction and oxido-reduction reactions rather than the seasons. In the past few decades, industrial development, and improved living standards have attracted many new immigrants to the study area and rapidly increased the demand for quality water in all sectors. Increasing urbanization and agricultural activities in the region have started to threaten the quality and usability of water. In this situation, using freshwater springs in the most efficient way, and finding new resources has become an urgent requirement. However, a detailed irrigation program and planning has not yet been made in the basin by 
spatial planners and water managers. There is also no serious study in terms of agricultural irrigation regarding spring waters. This hydrochemical assessment is the first study on this subject in the basin and its purpose is to evaluate the suitability of these water springs for use in irrigation based on the Geographic Information System (GIS) approach.

\section{Material and Methods}

The methods employed for this study are field measurements, sampling, laboratory analysis, and data interpretation. The geological and hydrogeological map of the basin was prepared by GIS methods, geological, geophysical and hydrogeological evaluations and utilizing the previous researches. In order to evaluate physicochemical parameters, 140 water samples collected from 10 different sources in the period of August 2017-September 2018 were analyzed in terms of main quality parameters by following standard test procedures. Geographical positions of sampling locations were measured with a portable GPS system. In situ measurements such as temperature $\left(\mathrm{T} ;{ }^{\circ} \mathrm{C}\right)$, electrical conductivity $\left(\mathrm{EC} ; \mu \mathrm{S} \mathrm{cm}{ }^{-1}\right)$, and hydrogen ion concentration $(\mathrm{pH})$ of the waters were measured using a portable multi-parameter water quality monitoring and testing equipment. Total Dissolved Solids (TDS; $\mathrm{mg} \mathrm{L}^{-1}$ ) were calculated from the sum of the concentrations of all major ions. The analysis of the waters was carried out in accordance with the standards specified in the "Turkish Regulation on Water Intended for Human Consumption" (Official

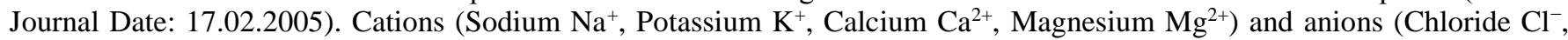
Sulfate $\mathrm{SO}_{4}{ }^{2-}$, Fluoride $\mathrm{F}^{-}$, Bicarbonate $\left.\mathrm{HCO}_{3}{ }^{-}\right)$, nitrate $\left(\mathrm{NO}_{3}{ }^{-}\right)$, nitrite $\left(\mathrm{NO}_{2}{ }^{-}\right)$, and ammonium $\left(\mathrm{NH}_{4}{ }^{+}\right)$were analyzed in the Denizli Municipality Health Branch Directorate, Denizli Environmental Quality Laboratory (DENÇEV, Denizli/TURKEY, a TS EN ISO/IEC 17025:2012 accredited Laboratory). Major ion contents in spring water samples were determined using ion chromatography. The methods used for the analysis of major ions are TS EN ISO 14911 for cations and SM 4110 B-TS EN ISO 10304-1 for anions. Obtained hydrochemical results were evaluated for hydro-geochemical facies analysis by plotting on Piper (1944), Gibbs (1970), and Chadha (1999) diagram. For irrigation water samples, Electrical Conductivity (EC), Total Dissolved Solids (TDS), total hardness (TH), percent sodium (Na\%), sodium adsorption ratio (SAR), magnesium ratio (MR), residual sodium carbonate (RSC), and residual sodium bicarbonate (RSBC) was assessed and compared with standard limits. Aquachem software package (version 2011.1.61) was used as a tool for hydro-geochemical calculation and evaluation for chemical data of spring waters.

Gökpınar Dam is located in Denizli City in the Aegean Region of Turkey. The catchment area of the dam is $228 \mathrm{~km}^{2}$ between

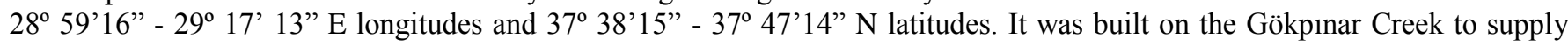
irrigation water. The dam provides irrigation services to an area of 5824 hectares at the downstream. There are 3100 hectares of agricultural land irrigated with spring waters in the dam basin. Western Turkey is one of the most seismically active regions in the World (Westaway 1993; Bozkurt 2003; Kocyigit 2005). Based on the hydrogeological characteristics of the lithological units in the basin, five hydrogeological units have been identified, which are Permeable rocks (Mesozoic limestone, Quaternary travertine), permeable clastic units (Quaternary alluvial fan), semipermeable rocks (Paleozoic gneiss, schist, quartzite, Eocene limestone), semipermeable clastic units (Quaternary alluvium), and impermeable units (Mesozoic clastic sediments, and Pliocene terrestrial clastic sediments) (Figure 1). The water table depth in the study area ranges between 5 and 40 meters (Taşdelen et al. 2016; Taşdelen 2018). Groundwater in the basin, as seen in the hydrogeology map, generally flows from the southeast to the northwest. Aquifers are recharged by rainfall seeping through the ground on the high elevation hills surrounding the basin. The geological units in the region have intense discontinuities due to tectonic stresses. The amount of groundwater flow in the basin is controlled by the density of the fault and fracture systems rather than the primary porosities of the units (Taşdelen et al. 2017). The highly jointed nature of the especially limestone and basement rocks makes the basin a rich hydrogeological reservoir. 10 water springs subject to this study feed the Gökpınar Creek flowing into the dam lake with a total flow of $1.5 \mathrm{~m}^{3} \mathrm{~s}^{-1}$. The main factor that determines groundwater hydrochemistry along the flow path from recharges to discharge areas in the aquifers of the study area is the chemical composition of the geological units. The chemical composition of the waters and the regional geological features of the basin show that groundwater chemistry in the study area is controlled by the decomposition processes of carbonates, silicates, and evaporites, which are abundant in the region. The region is very suitable for agriculture due to its mild climate, fertile soil, and the presence of water. Agriculture is the most important means of livelihood for local people in the study area. Almost all of them deal with traditional Mediterranean agriculture such as olives, grapes, figs, melons, watermelons, almonds, and pomegranates. The green vegetable and fruit agriculture of this region is also well known. The springs are also used for drinking, domestic use, and trout farming purposes in the settlements within the basin. 


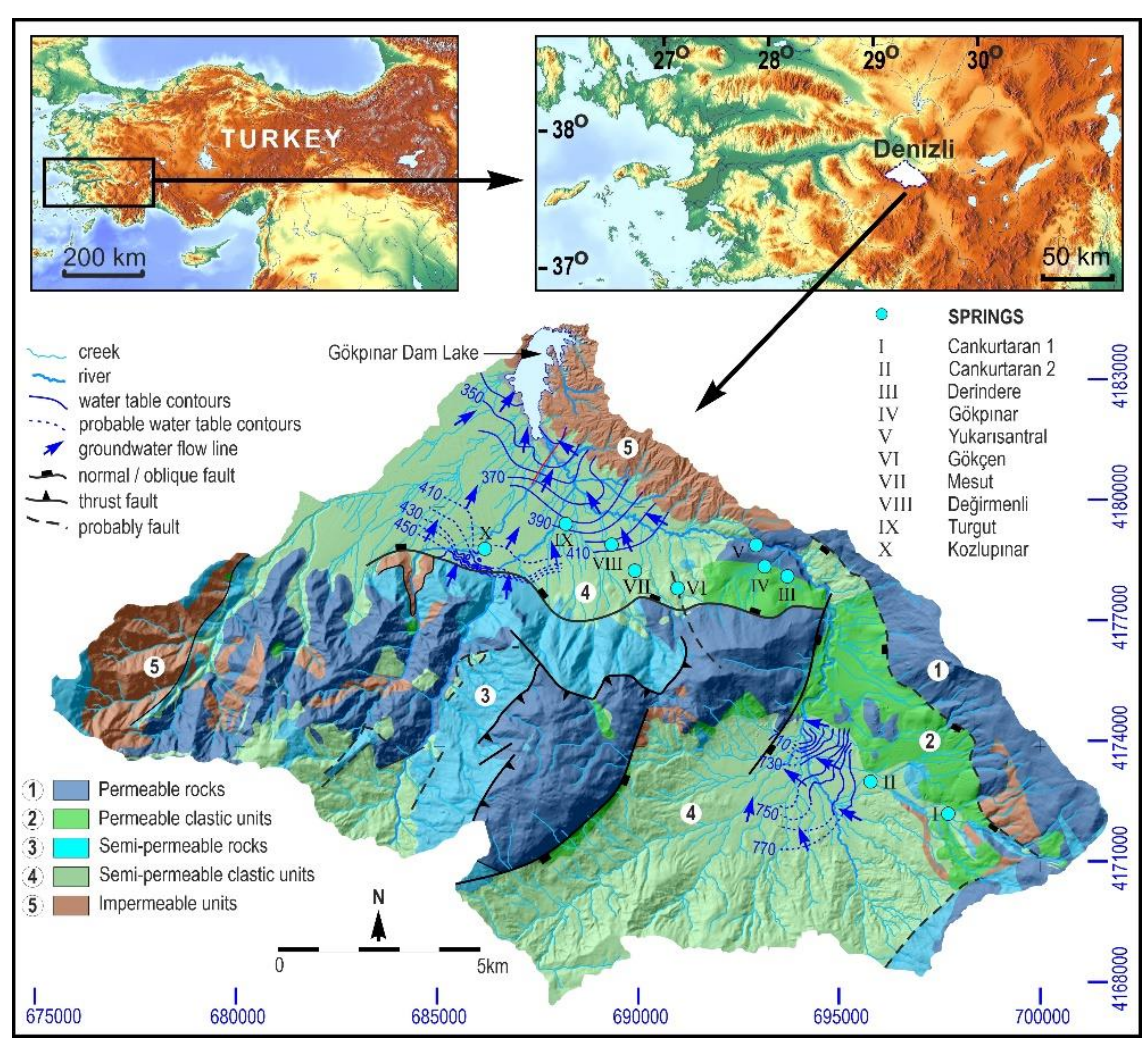

Figure 1- Hydrogeological map of the Gökpınar Dam Basin (compiled from Okay (1989), Taşdelen et al. (2017) and MTA (2018))

\section{Results and Discussions}

\subsection{Water chemistry}

The statistical summary of long-term physical parameters and chemical analyses results of each spring in the Basin (on the basis of $\mathrm{mg} \mathrm{L}^{-1}$ for ions) are presented in Table 1 . The long-term average major ion contents of springs based on the milliequivalent percentage are illustrated in the $\mathrm{pH}$ of the spring water samples in the basin ranges from 7.2 to 7.5 and with an average of 7.33 shows alkaline nature. (Table 1). The temperature of springs ranges from 14.5 to $19.7^{\circ} \mathrm{C}$. During the monitoring period, the long-term average EC and TDS content of the spring waters in the dam basin range from 402 to $691 \mu \mathrm{S} \mathrm{cm}{ }^{-1}$ and 367 to $681 \mathrm{mg}$ $\mathrm{L}^{-1}$, respectively. The springs having relatively high conductivity in the basin are Cankurtaran-2, Değirmenli, and Turgut. Natural waters contain some dissolved solid substances of organic or inorganic geological units with which they come into contact. The total dissolved solids (TDS) in the spring waters is a measure of organic and inorganic substances dissolved in water and in terms of groundwater depends on the solubility of geological units in water. High TDS value can restrict use for irrigation and reduce crop yield (Catroll 1962; Freeze \& Cherry 1979). The alluvial aquifers are loose, unconsolidated, eroded, carried, and redeposited soil or sediment environments that made up of a variety of materials, including fine particles of clay, silt, sand, and gravel. Also, evaporation of waters from shallow alluvial aquifers, where the water table is near the land surface, increases total dissolved solids in the groundwater. Cankurtaran-2, Değirmenli, and Turgut springs are alluvial springs. Aquifers feeding the springs consist of semipermeable clastic units. The relatively high TDS values of these three sources are for the reasons mentioned above. However, this high amount is relative and there is no problem in terms of irrigation water quality. According to TDS classification (Catroll 1962; Freeze \& Cherry 1979), all sources including Cankurtaran-2, Değirmenli, and Turgut are of freshwater type (TDS $<1.000 \mathrm{mg} \mathrm{L}^{-1}$ ) (Table 2) and suitable for irrigation purposes. Among the nutrients, the long-term average concentrations of $\mathrm{NO}_{3}{ }^{-}, \mathrm{NO}_{2}{ }^{-}$and $\mathrm{NH}_{4}{ }^{+}$ions ranged from 4.2 to $16.2,0$ to 0.1 and 0 to $0.49 \mathrm{mg} \mathrm{L}^{-1}$, respectively. Cankurtaran-2 Değirmenli and Turgut have the highest concentrations of $\mathrm{NO}_{3}{ }^{-}$in the basin (Table 1). In the alluvial environments of the basin, nitrate can be carried to surface and groundwater by direct discharge or leakage from the soil from artificial sources such as agricultural areas and settlements. These springs are vulnerable to surface contaminants, as they can recharge directly from the floor surface. Therefore, the reason for relatively high $\mathrm{NO}_{3}{ }^{-}$concentration is thought to be of an anthropogenic. Nitrate, Nitrite, and ammonium concentrations of waters were within the recommended values for drinking water (Ayers \& Westcot 1985). The abundance of major ions based on the meq $\%$ in spring waters is in the following order: $\mathrm{HCO}_{3}^{-}>\mathrm{Ca}^{2+}>\mathrm{Mg}^{2+}>\mathrm{SO}_{4}^{2-}>\mathrm{Na}^{+}>$ $\mathrm{Cl}^{-}>\mathrm{NO}_{3}^{-}>\mathrm{K}^{+}>\mathrm{F}^{-}$. The most abundant cations $\left(\mathrm{mg} \mathrm{L}^{-1}\right.$ ) present in waters are $\mathrm{Ca}$ (72.1 to 93.8), $\mathrm{Mg}$ (10.4 to 29.9), $\mathrm{Na}(2.6$ to 6.6), and $\mathrm{K}$ (0.4 to 1.2); the most abundant anions ( $\mathrm{mg} \mathrm{L}^{-1}$ ) are $\mathrm{HCO}_{3}^{-}$(228.5 to 405.4), $\mathrm{Cl}^{-}$(2.8 to 9.2), and $\mathrm{SO}_{4}{ }^{2-}$ (4.9 to 56.7), and $\mathrm{F}(0.05$ to 0.61$)$. According to this sequence, lithological facies that are dominant in the composition of spring waters are carbonated rock minerals (Calcite, dolomite) and evaporitic sulfate minerals (gypsum, halite); secondarily, they are plagioclase minerals originating from igneous and metamorphic rocks. 


\begin{tabular}{|c|c|c|c|c|c|c|c|c|c|c|c|c|}
\hline & $\underset{\mathfrak{\Xi}}{\mathfrak{\Xi}}$ & & 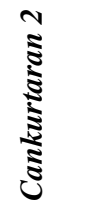 & 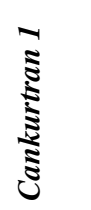 & 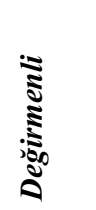 & 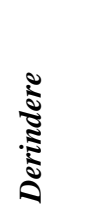 & 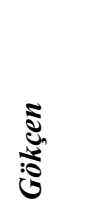 & 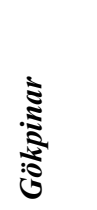 & $\begin{array}{l}\mathbf{5} \\
\text { క } \\
\frac{5}{5}\end{array}$ & $\underset{\mathfrak{s}}{\mathfrak{s}}$ & $\underset{5}{5}$ & 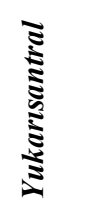 \\
\hline Parameter & & & 15 & 15 & 16 & 16 & 14 & 16 & 9 & 15 & 16 & 8 \\
\hline \multirow{4}{*}{$\mathrm{Cl}^{-}$} & $\mathrm{mg} \mathrm{L}^{-1}$ & Avg. & 4.5 & 3.0 & 8.2 & 2.8 & 3.5 & 4.4 & 5.5 & 7.3 & 8.3 & 4.7 \\
\hline & $\mathrm{mg} \mathrm{L}^{-1}$ & Max. & 6.4 & 8.9 & 10.3 & 6.7 & 4.4 & 6.4 & 6.1 & 7.9 & 9.2 & 5.6 \\
\hline & $\mathrm{mg} \mathrm{L}^{-1}$ & Min. & 3.7 & 2.2 & 7.4 & 2.4 & 3.1 & 3.7 & 3.7 & 6.9 & 8.1 & 4.3 \\
\hline & & Std. & 0.8 & 1.7 & 0.8 & 1.1 & 0.4 & 0.8 & 0.7 & 0.3 & 0.3 & 0.4 \\
\hline \multirow{4}{*}{$\mathbf{F}^{-}$} & $\mathrm{mg} \mathrm{L}^{-1}$ & Avg. & 0.06 & 0.05 & 0.07 & 0.14 & 0.06 & 0.61 & 0.26 & 0.06 & 0.08 & 0.09 \\
\hline & $\mathrm{mg} \mathrm{L}^{-1}$ & Max. & 0.07 & 0.06 & 0.09 & 0.17 & 0.07 & 8.10 & 0.31 & 0.08 & 0.11 & 0.11 \\
\hline & $\mathrm{mg} \mathrm{L}^{-1}$ & Min. & 0.03 & 0.04 & 0.05 & 0.12 & 0.04 & 0.07 & 0.13 & 0.04 & 0.06 & 0.07 \\
\hline & & Std. & 0.01 & 0.01 & 0.01 & 0.01 & 0.01 & 2.00 & 0.06 & 0.01 & 0.02 & 0.01 \\
\hline \multirow{4}{*}{$\mathrm{HCO}_{3}^{-}$} & $\mathrm{mg} \mathrm{L}^{-1}$ & Avg. & 393.4 & 279.1 & 405.4 & 228.5 & 346.5 & 304.0 & 271.5 & 358.8 & 400.0 & 302.3 \\
\hline & $\mathrm{mg} \mathrm{L}^{-1}$ & Max. & 464.3 & 293.1 & 439.2 & 239.1 & 361.1 & 319.6 & 315.7 & 372.0 & 418.2 & 312.4 \\
\hline & $\mathrm{mg} \mathrm{L}^{-1}$ & Min. & 263.0 & 260.6 & 378.4 & 213.1 & 333.6 & 283.5 & 257.6 & 342.5 & 365.1 & 296.8 \\
\hline & & Std. & 72.1 & 9.4 & 14.6 & 6.3 & 6.7 & 7.7 & 17.3 & 8.2 & 12.6 & 6.1 \\
\hline \multirow{4}{*}{$\mathrm{SO}_{4}{ }^{2-}$} & $\mathrm{mg} \mathrm{L}^{-1}$ & Avg. & 26.5 & 27.2 & 14.2 & 56.7 & 4.9 & 48.4 & 44.0 & 8.3 & 18.7 & 40.0 \\
\hline & $\mathrm{mg} \mathrm{L}^{-1}$ & Max. & 30.3 & 62.9 & 25.1 & 59.6 & 5.5 & 51.2 & 47.4 & 8.7 & 28.2 & 41.5 \\
\hline & $\mathrm{mg} \mathrm{L}^{-1}$ & Min. & 20.4 & 20.5 & 11.0 & 55.1 & 4.6 & 46.0 & 41.1 & 7.8 & 12.0 & 38.0 \\
\hline & & Std. & 3.7 & 10.1 & 3.6 & 1.4 & 0.3 & 1.6 & 1.9 & 0.3 & 4.8 & 1.2 \\
\hline \multirow{4}{*}{$\mathrm{Ca}^{2+}$} & $\mathrm{mg} \mathrm{L}^{-1}$ & Avg. & 83.8 & 73.0 & 93.8 & 73.0 & 80.0 & 86.7 & 72.1 & 88.8 & 91.6 & 85.9 \\
\hline & $\mathrm{mg} \mathrm{L}^{-1}$ & Max. & 94.9 & 88.5 & 101.7 & 76.1 & 83.3 & 90.7 & 86.1 & 92.3 & 94.5 & 88.7 \\
\hline & $\mathrm{mg} \mathrm{L}^{-1}$ & Min. & 70.9 & 67.6 & 87.6 & 69.8 & 76.9 & 84.1 & 68.2 & 84.8 & 80.4 & 84.3 \\
\hline & & Std. & 8.3 & 5.0 & 3.4 & 1.6 & 1.5 & 1.5 & 5.4 & 2.1 & 3.5 & 1.7 \\
\hline \multirow{4}{*}{$\mathrm{Mg}^{2+}$} & $\mathrm{mg} \mathrm{L}^{-1}$ & Avg. & 29.9 & 13.4 & 23.0 & 11.5 & 15.6 & 16.1 & 21.6 & 18.0 & 10.4 & 15.9 \\
\hline & $\mathrm{mg} \mathrm{L}^{-1}$ & Max. & 37.0 & 25.1 & 24.6 & 11.8 & 16.3 & 16.4 & 23.0 & 18.6 & 24.7 & 16.1 \\
\hline & $\mathrm{mg} \mathrm{L}^{-1}$ & Min. & 12.1 & 10.8 & 21.5 & 11.1 & 15.0 & 15.7 & 16.7 & 17.2 & 0.0 & 15.6 \\
\hline & & Std. & 6.6 & 3.5 & 0.7 & 0.2 & 0.3 & 0.2 & 1.9 & 0.4 & 8.9 & 0.1 \\
\hline \multirow{4}{*}{$\mathbf{K}^{+}$} & $\mathrm{mg} \mathrm{L}^{-1}$ & Avg. & 0.9 & 0.9 & 0.8 & 0.4 & 0.5 & 0.5 & 0.6 & 0.6 & 1.2 & 0.4 \\
\hline & $\mathrm{mg} \mathrm{L}^{-1}$ & Max. & 1.4 & 1.2 & 1.3 & 0.6 & 1.0 & 0.8 & 0.7 & 0.7 & 2.2 & 0.5 \\
\hline & $\mathrm{mg} \mathrm{L}^{-1}$ & Min. & 0.7 & 0.7 & 0.5 & 0.3 & 0.4 & 0.2 & 0.5 & 0.4 & 0.7 & 0.4 \\
\hline & & Std. & 0.2 & 0.1 & 0.2 & 0.1 & 0.2 & 0.1 & 0.1 & 0.1 & 0.4 & 0.0 \\
\hline \multirow{4}{*}{$\mathrm{Na}^{+}$} & $\mathrm{mg} \mathrm{L}^{-1}$ & Avg. & 6.6 & 3.4 & 6.3 & 2.6 & 2.8 & 3.6 & 5.9 & 4.6 & 6.3 & 3.5 \\
\hline & $\mathrm{mg} \mathrm{L}^{-1}$ & Max. & 12.0 & 6.0 & 6.9 & 2.9 & 3.3 & 4.5 & 6.4 & 4.8 & 6.7 & 3.8 \\
\hline & $\mathrm{mg} \mathrm{L}^{-1}$ & Min. & 3.4 & 3.1 & 5.7 & 2.5 & 2.6 & 2.9 & 3.3 & 4.2 & 5.9 & 3.3 \\
\hline & & Std. & 1,7 & 0.7 & 0.3 & 0.1 & 0.2 & 0.5 & 1.0 & 0.2 & 0.2 & 0.2 \\
\hline \multirow{4}{*}{$\mathrm{NO}_{3}^{-}$} & $\mathrm{mg} \mathrm{L}^{-1}$ & Avg. & 13.7 & 4.2 & 16.2 & 9.6 & 4.9 & 7.4 & 4.2 & 10.6 & 15.9 & 8.0 \\
\hline & $\mathrm{mg} \mathrm{L}^{-1}$ & Max. & 30.7 & 31.2 & 21.4 & 11.2 & 6.1 & 7.9 & 8.7 & 11.4 & 18.0 & 8.7 \\
\hline & $\mathrm{mg} \mathrm{L}^{-1}$ & Min. & 1.8 & 0.6 & 14.4 & 9.0 & 0.3 & 7.0 & 2.9 & 9.7 & 12.4 & 7.5 \\
\hline & & Std. & 9.3 & 7.8 & 1.8 & 0.5 & 1.4 & 0.2 & 2.0 & 0.4 & 1.4 & 0.3 \\
\hline \multirow{4}{*}{$\mathrm{NH}_{4}{ }^{+}$} & $\mathrm{mg} \mathrm{L}^{-1}$ & Avg. & 0.23 & 0.19 & 0.17 & 0.49 & 0.22 & 0.46 & - & 0.19 & - & - \\
\hline & $\mathrm{mg} \mathrm{L}^{-1}$ & Max. & 0.25 & 0.23 & 0.17 & 1.12 & 0.29 & 0.46 & 0.00 & 0.19 & 0.00 & 0.0 \\
\hline & $\mathrm{mg} \mathrm{L}^{-1}$ & Min. & 0.20 & 0.17 & 0.17 & 0.26 & 0.16 & 0.6 & 0.00 & 0.19 & 0.00 & 0.0 \\
\hline & & Std. & 0.04 & 0.03 & - & 0.42 & 0.07 & - & - & - & - & - \\
\hline \multirow{4}{*}{$\mathrm{NO}_{2}{ }^{-}$} & $\mathrm{mg} \mathrm{L}^{-1}$ & Avg. & 0.1 & 0.1 & 0.1 & 0.1 & 0.1 & 0.1 & 0.0 & 0.1 & 0.0 & 0.1 \\
\hline & $\mathrm{mg} \mathrm{L}^{-1}$ & Max. & 0.2 & 0.2 & 0.2 & 0.2 & 0.2 & 0.2 & 0.1 & 0.2 & 0.0 & 0.1 \\
\hline & $\mathrm{mg} \mathrm{L}^{-1}$ & Min. & 0.0 & 0.0 & 0.0 & 0.0 & 0.0 & 0.0 & 0.0 & 0.0 & 0.0 & 0.0 \\
\hline & & Std. & 0.1 & 0.1 & 0.1 & 0.1 & 0.1 & 0.1 & 0.0 & 0.1 & 0.0 & 0.0 \\
\hline \multirow{4}{*}{ TDS } & $\mathrm{mg} \mathrm{L}^{-1}$ & Avg. & 566 & 406 & 569 & 387 & 460 & 475 & 427 & 499 & 567 & 462 \\
\hline & $\mathrm{mg} \mathrm{L}^{-1}$ & Max. & 681 & 464 & 622 & 403 & 478 & 494 & 482 & 516 & 590 & 477 \\
\hline & $\mathrm{mg} \mathrm{L}^{-1}$ & Min. & 381 & 372 & 530 & 367 & 444 & 461 & 410 & 476 & 523 & 454 \\
\hline & & Std. & 88 & 27 & 23 & 8 & 8 & 8 & 21 & 11 & 17 & 9 \\
\hline \multirow{4}{*}{ pH } & & Avg. & 7.3 & 7.5 & 7.2 & 7.3 & 7.4 & 7.3 & 7.4 & 7.2 & 7.3 & 7.4 \\
\hline & & Max. & 7.6 & 8.0 & 7.4 & 7.7 & 7.8 & 7.6 & 7.6 & 7.5 & 7.7 & 7.6 \\
\hline & & Min. & 6.9 & 7.0 & 7.0 & 6.9 & 7.0 & 6.8 & 6.9 & 6.9 & 7.0 & 7.1 \\
\hline & & Std. & 0.2 & 0.3 & 0.1 & 0.2 & 0.2 & 0.2 & 0.3 & 0.2 & 0.2 & 0.2 \\
\hline
\end{tabular}


Table 2- Irrigation water classifications of the springs (The spring numbers and names are shown in Figure 1)

\begin{tabular}{|c|c|c|c|c|c|c|}
\hline Parameter & Unit & Reference & Analytical method & Ranges & Class & Spring number \\
\hline TDS & $\mathrm{mg} \mathrm{L}^{-1}$ & $\begin{array}{l}\text { Catroll } \\
1962 ; \\
\text { Freeze } \\
\text { \& Cherry } \\
1979\end{array}$ & $T D S=0.65 \times E C$ & $\begin{array}{c}<1000 \\
1000-10.000 \\
0.000-100.000 \\
>100.000\end{array}$ & $\begin{array}{l}\text { Fresh water } \\
\text { Brackish water } \\
\text { Saline water } \\
\text { Brine water }\end{array}$ & From I to $\mathrm{X}$ \\
\hline EC & $\mu \mathrm{S} \mathrm{cm}-1$ & $\begin{array}{l}\text { Richards } \\
1954\end{array}$ & pH / EC / TDS meter & $\begin{array}{c}<250 \\
250-750 \\
750-2000 \\
2000-3000 \\
>3000\end{array}$ & $\begin{array}{l}\text { Excellent } \\
\text { Good } \\
\text { Permissible } \\
\text { Doubtful } \\
\text { Unsuitable }\end{array}$ & From I to $\mathrm{X}$ \\
\hline TH & meq $\mathrm{L}^{-1}$ & $\begin{array}{l}\text { Sawyer \& } \\
{ }^{1} \text { Mc-Cartly } \\
1967\end{array}$ & $T H=\left(\mathrm{Ca}^{2+}+\mathrm{Mg}^{2+}\right) \operatorname{meq} L^{-1} \times 50$ & $\begin{array}{c}<75 \\
75-150 \\
150-300 \\
>300\end{array}$ & $\begin{array}{l}\text { Soft } \\
\text { Moderately hard } \\
\text { Hard } \\
\text { Very hard }\end{array}$ & $\begin{array}{l}\text { II, IV, V, VI, VII, VIII, X } \\
\text { I, III, IX, }\end{array}$ \\
\hline $\mathrm{Na} \%$ & $\%$ & $\begin{array}{l}\text { Wilcox } \\
1955\end{array}$ & $\% N a=\frac{r N a^{+} \times 100}{r N a^{+}+r C a^{2+}+r M g^{2+}+r K^{+}}$ & $\begin{array}{c}0-20 \\
20-40 \\
40-60 \\
60-80 \\
>80\end{array}$ & $\begin{array}{l}\text { Excellent } \\
\text { Good } \\
\text { Permissible } \\
\text { Doubtful } \\
\text { Unsuitable }\end{array}$ & From I to $\mathrm{X}$ \\
\hline SAR & meq $\mathrm{L}^{-1}$ & $\begin{array}{l}\text { Richards } \\
1954 ; \\
\text { Todd } 1960\end{array}$ & $S A R=\frac{N a^{+}}{\sqrt{\frac{\left(C a^{2+}+M g^{2+}\right)}{2}}}$ & $\begin{array}{c}<10 \\
10-18 \\
19-26 \\
>26\end{array}$ & $\begin{array}{l}\text { Excellent (S1) } \\
\text { Good (S2) } \\
\text { Doubtful (S3) } \\
\text { Unsuited (S4-S5) }\end{array}$ & From $\mathrm{I}$ to $\mathrm{X}$ \\
\hline RSC & $\operatorname{meq} \mathrm{L}^{-1}$ & $\begin{array}{l}\text { Eaton } \\
1950 ; \\
\text { Richards } \\
1954\end{array}$ & $R S C=\left(\mathrm{CO}_{3}^{2-}+\mathrm{HCO}_{3}^{-}\right)-\left(\mathrm{Ca}^{2+}+\mathrm{Mg}^{2+}\right)$ & $\begin{array}{c}<1.25 \\
1.25-2.5 \\
>2.5\end{array}$ & $\begin{array}{l}\text { Good } \\
\text { Doubtful } \\
\text { Unsuitable }\end{array}$ & $\begin{array}{l}\text { I, II, III, IV, V, VII, X } \\
\text { VI, VIII, IX }\end{array}$ \\
\hline RSBC & meq $\mathrm{L}^{-1}$ & ${ }^{1}$ Eaton 1950 & $\mathrm{RSBC}=\mathrm{HCO}_{3}^{-}-\mathrm{Ca}^{2+}$ & $\begin{aligned} & <5 \\
5 & -10 \\
> & 10\end{aligned}$ & $\begin{array}{l}\text { Satisfactory } \\
\text { Marginal } \\
\text { Unsatisfactory }\end{array}$ & From $\mathrm{I}$ to $\mathrm{X}$ \\
\hline MR & $\%$ & $\begin{array}{l}\text { Szabolcs \& } \\
\text { Darab } 1964\end{array}$ & $M R=\frac{M g^{2+}}{M g^{2+}+C a^{2+}} x 100$ & $\begin{array}{l}<50 \\
>50\end{array}$ & $\begin{array}{l}\text { Suitable } \\
\text { Unsuitable }\end{array}$ & From I to $\mathrm{X}$ \\
\hline
\end{tabular}

\subsection{Water facies and hydrochemical evaluation}

Piper Diagram (Piper AM 1944): A Piper diagram was plotted using the analytic data obtained from the hydrochemical analysis of the basin spring waters. Waters of similar nature will tend to be a group together on the Piper diagram. In general, the dominant water type is $\mathrm{Ca}^{2+}-\mathrm{Mg}^{2+}-\mathrm{HCO}_{3}^{-}$. The dominant water types of springs reflect the rock interactions with limestone and dolomite dominated formations and weathering of silicate minerals in the aquifer. In addition to dolomite, the increase in $\mathrm{Mg}$ can result from magmatic rock minerals (olivine, biotite, hornblende, augite, etc) and minerals such as serpentine, diopside, tremolite in metamorphic rocks. All spring water samples characterized as alkaline earth metals $\left(\mathrm{Ca}^{2+}, \mathrm{Mg}^{2+}\right)$ are dominant over the alkalies $\left(\mathrm{Na}^{+}, \mathrm{K}^{+}\right)$. The weak acidic anions $\left(\mathrm{CO}_{3}{ }^{2-}, \mathrm{HCO}^{3-}\right)$ exceed the strong acidic anions $\left(\mathrm{Cl}^{-}, \mathrm{SO}_{4}{ }^{2-}\right)$ in all samples (Figure 2).

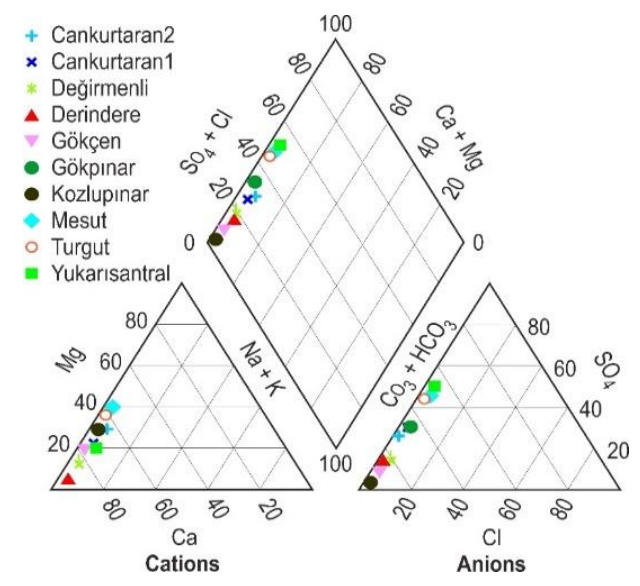

Figure 2- Piper diagram of spring waters 
Chadha Diagram (Chadha DK 1999): To classify the spring waters as geochemically and to identify the hydrochemical processes based on prevailing ions, Chadha (1999) diagram is used (Figure 3a). In all the basin spring waters, alkaline earths $\left(\mathrm{Ca}^{2+}, \mathrm{Mg}^{2+}\right)$ and weak acidic anions $\left(\mathrm{HCO}_{3}^{-}\right)$exceed alkali metals $\left(\mathrm{Na}^{+}, \mathrm{K}^{+}\right)$and strong acidic anions $\left(\mathrm{SO}_{4}{ }^{2-}, \mathrm{Cl}^{-}\right)$. This type of water may be due to the dissolution of carbonates in the aquifer material and the decomposition of silicate minerals.

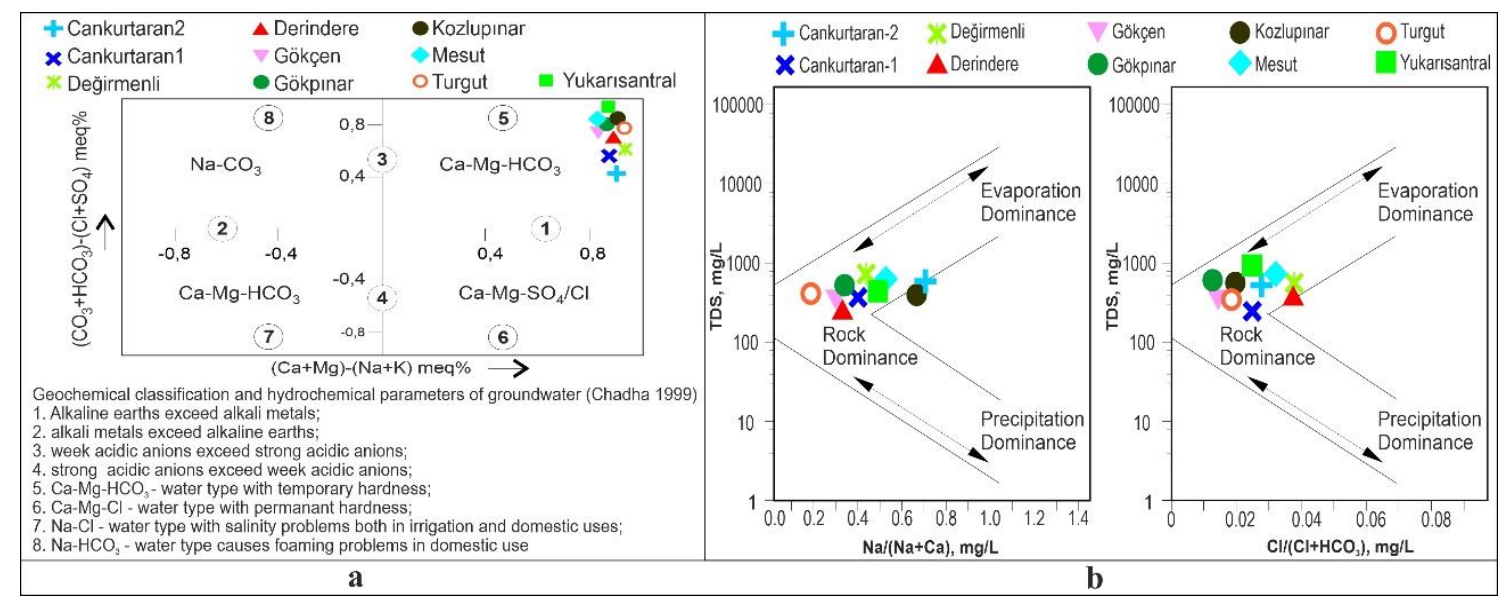

Figure 3- Chadha (1999) (a) and Gibbs (1970) (b) diagrams of spring waters

Gibbs Plot (Gibbs RJ 1970): Gibbs, proposed a diagram to identify the relationship between the water composition and properties of the aquifer units. Three distinct areas such as "precipitation dominance", "evaporation dominance" and "rock dominance" are indicated in the diagram. Gibbs plot specifies that all the basin spring water samples fall in the "rock dominance area" (Figure 3b). Falling in rock dominance area indicates that the precipitation sourced chemical weathering of rock-forming minerals are influencing the spring water geochemistry. That is, the dominant mechanism controlling groundwater major ion chemistry in the basin is rock-water interaction.

Correlation analysis: The correlation matrix has been widely used to determine the relationships between the hydrochemical components of natural waters (Tiwari 2011). If there is a good relationship between any two variables, the correlation coefficient is close to 1 or 1 (high correlation); on the contrary, if there is no relationship, the value is 0 (Table 3 ). The relationship between the components in the spring waters was determined using Pearson correlation analysis (Table 3). Correlation significant at the 0.01 and 0.05 levels was found between some physical parameters and major elements. There is a strong positive correlation between TDS, cations $\left(\mathrm{Ca}^{2+}, \mathrm{Na}^{+}, \mathrm{Mg}^{2+}\right)$, and anions $\left(\mathrm{Cl}^{-}, \mathrm{SO}_{4}{ }^{2-}, \mathrm{HCO}^{3-}\right)$ in the spring waters. This confirms the results obtained with the Chadha and Gibbs diagrams. The dominant hydrochemical processes that determine the composition of waters are rockwater interaction and ionic changes. In particular, the strong correlation between TDS, $\mathrm{Ca}^{2+}$, and $\mathrm{HCO}^{3-}$ may result from the presence of lithologically dominant karstic aquifers in the region. In addition, the strong correlation between $\mathrm{TDS}^{-\mathrm{NO}_{3}}{ }^{-} \mathrm{Na}^{+}$, and $\mathrm{Cl}^{-}$may also be a result of human activities.

\subsection{Irrigation water quality}

Since only absolute ion concentration values may not be sufficient to determine the suitability of water for irrigation use, the effects of interactions between ions on the chemical properties of water should also be evaluated (Nagaraju et al. 2014). Therefore, in the next sections, the methods that include the interactions were evaluated (Table 2).

Total Dissolved Solids (TDS): The minimum and maximum values of TDS in the water samples of the springs in the basin are between 387 and $569 \mathrm{mg} \mathrm{L}^{-1}$. According to TDS classification (Catroll 1962; Freeze \& Cherry 1979), all of the springs are freshwater type (TDS $<1.000 \mathrm{mg} \mathrm{L}^{-1}$ ) (Table 2) and suitable for irrigation purposes.

Electrical Conductivity (EC): According to Richards (1954), electrical conductivity classification, the lowest and highest EC values of the spring waters in the basin during the monitoring period ranged from are 402 to $691 \mu \mathrm{S} \mathrm{cm}-1$ and "Good" class (Table 2).

Total Hardness (TH): The hardness classification of spring waters (Table 2) (Sawyer \& Mc-Cartly 1967) shows that most of the samples in the region is "hard" while Cankurtaran-2 (332 mg L-1), Degirmenli (329 mg L-1) and Turgut Pınarı (330 mg L-1) Springs are classified as "very hard". The lowest and highest values of the total hardness of the springs in the dam basin are between 213 - $389 \mathrm{mg} \mathrm{L}^{-1}$.

Sodium Percentage $(\mathrm{Na} \%)$ : Sodium concentration is an important parameter for defining the quality of agricultural irrigation water due to specific harmful effects on soil physical properties (Eaton 1950; Doneen 1962; Raju 2007). The long-term average sodium percent ( $\mathrm{Na} \%$ ) of the basin springs ranges from 1.29 to 9.28. According to the Na\% classification (Wilcox 1955), all of springs classified as "excellent - S1" (Table 2). 
Wilcox diagram: One of the most used methods to determine irrigation water quality is the Wilcox (1955) diagram, based on the $\mathrm{Na} \%$ and EC graph (Figure 4a). All springs fall within the category of "excellent to good" in Wilcox (1955) Diagram according to their sodium percentage are suitable for irrigation purpose.

Sodium Absorption Ratio (SAR): The calculated long-term average SAR values as a range $0.07-0.16$ meq $\mathrm{L}^{-1}$ indicate that the spring water samples are excellent for irrigation purposes (Richards, 1954). Also, all samples are "good quality - C2" due to electrical conductivity values of $438-617 \mu \mathrm{S} / \mathrm{cm}$ (Richards 1954) (Table 2). All of the water samples fall in the C2 - S1 class showing "medium salinity" hazard and "low sodium" hazard. These waters can be used to "irrigate all types of soils with little danger of exchangeable sodium" according to Richards (1954) definition (Figure 4b).
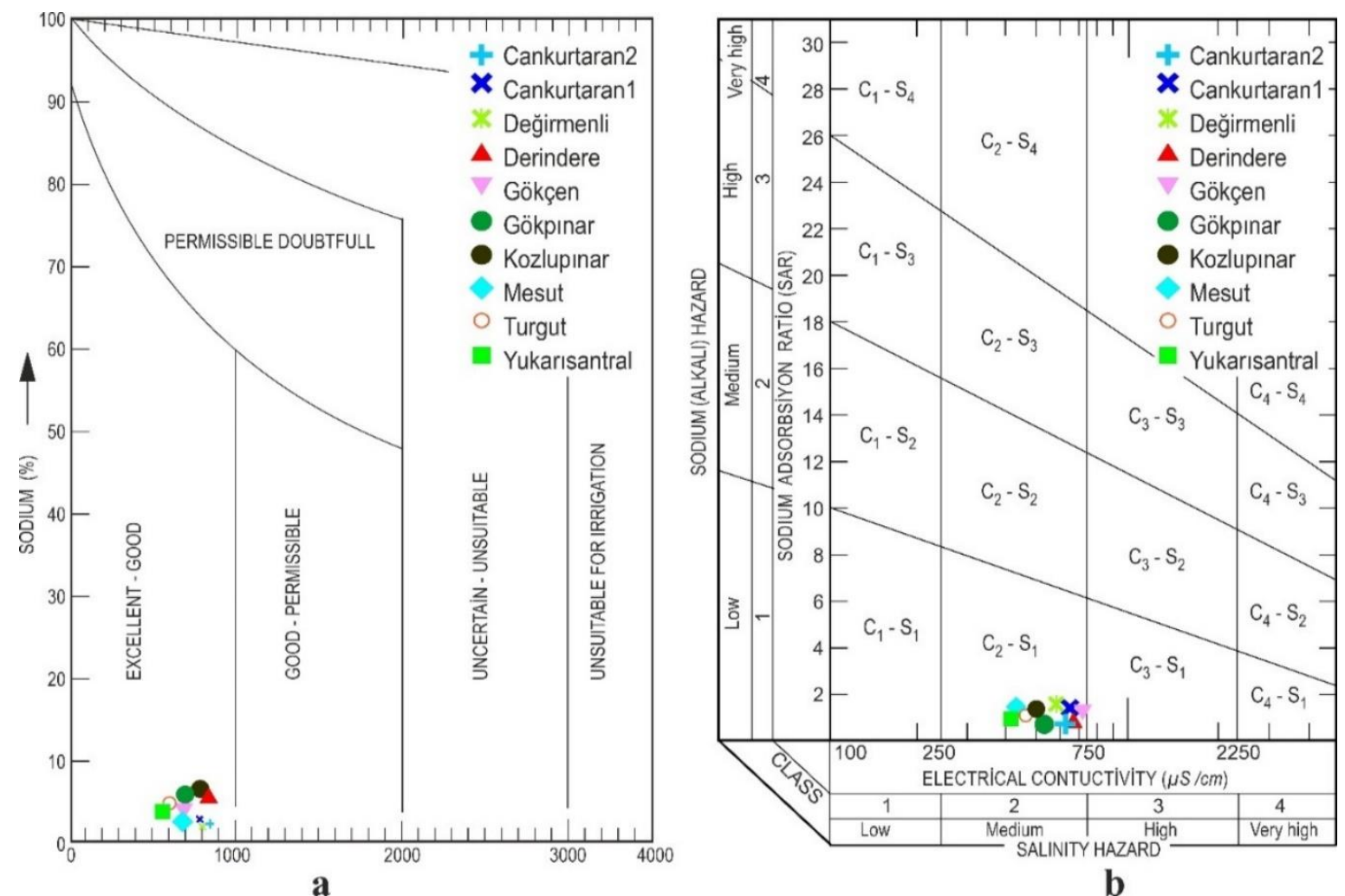

b

Figure 4- Wilcox (1955) (a) and USSL (Richards 1954) (b) diagrams

Residual Sodium Carbonate (RSC): The calculations showed that the long-term average RSC values of the basin spring waters range from -0.92 to 0.4 meq $\mathrm{L}^{-1}$ and water samples are within the safe water category "good" for irrigation (Eaton 1950 , Richards 1954) (Table 2). The lowest and highest values of the RSC of the springs in the basin are between $-1.3-0.47$ meq $\mathrm{L}^{-1}$. Based on the RSC, the springs in the "doubtful” category are Gökçen, Değirmenli, and Turgut Pınarı (Table 2).

Residual Sodium Bicarbonate (RSBC): RSBC values of water samples vary from 0.10 to 2.3 meq $\mathrm{L}^{-1}$. Therefore, RSBC values of all spring waters are smaller than five, all of them considered "Satisfactory" for irrigation (Eaton 1950; Richards 1969) (Table 2).

Magnesium Ratio (MR): The lowest and highest values of MR of the spring samples in the basin are between $19.8 \%-39.4 \%$. The springs of Cankurtaran-2 and Kozlupinar are the waters with the highest MR. The fact that the MR value of all the spring samples is below 50 indicates that all springs in the dam basin are not harmful for irrigation in terms of magnesium content (Raghunath 1987; Szabolcs \& Darab 1964) (Table 2). 
Table 3- Pearson correlation coefficients of variables taken for spring waters

\begin{tabular}{|c|c|c|c|c|c|c|c|c|c|c|c|c|}
\hline & $\mathrm{Cl}^{-}$ & $F^{-}$ & $\mathrm{HCO}_{3}^{-}$ & $\mathrm{SO}_{4}^{2-}$ & $\mathrm{Ca}^{2+}$ & $M^{2+}$ & $K^{+}$ & $\mathrm{Na}^{+}$ & $\mathrm{NO}_{3}{ }^{-}$ & $\mathrm{NO}_{2}^{-}$ & $T D S$ & $p H$. \\
\hline $\mathrm{Cl}^{-}$ & 1 & & & & & & & & & & & \\
\hline $\mathrm{F}^{-}$ & -0.242 & 1 & & & & & & & & & & \\
\hline $\mathrm{HCO}_{3}{ }^{-}$ & $0.847^{*}$ & -0.328 & 1 & & & & & & & & & \\
\hline $\mathrm{SO}_{4}{ }^{2-}$ & -0.440 & 0.574 & -0.760 & 1 & & & & & & & & \\
\hline $\mathrm{Ca}^{2+}$ & 0.692 & -0.029 & $0.814^{*}$ & -0.484 & 1 & & & & & & & \\
\hline $\mathrm{Mg}^{2+}$ & 0.592 & -0.061 & 0.416 & -0.155 & 0.150 & 1 & & & & & & \\
\hline $\mathrm{K}^{+}$ & 0.613 & -0.333 & 0.616 & -0.422 & 0.320 & 0.083 & 1 & & & & & \\
\hline $\mathrm{Na}^{+}$ & $0.812^{*}$ & -0.156 & 0.681 & -0.277 & 0.449 & 0.610 & 0.682 & 1 & & & & \\
\hline $\mathrm{NO}_{3}{ }^{-}$ & $0.807^{*}$ & -0.276 & 0.733 & -0.290 & 0.755 & 0.237 & 0.540 & 0.646 & 1 & & & \\
\hline $\mathrm{NO}_{2}^{-}$ & -0.268 & -0.067 & -0.059 & -0.073 & 0.067 & 0.138 & -0.443 & -0.515 & -0.067 & 1 & & \\
\hline TDS & $0.819^{*}$ & -0.185 & $0.958^{*}$ & -0.545 & $0.851^{*}$ & 0.466 & 0.610 & $0.773^{*}$ & $0.838^{*}$ & -0.119 & 1 & \\
\hline pH. & -0.633 & -0.043 & -0.524 & 0.225 & -0.692 & -0.273 & -0.063 & -0.415 & -0.760 & -0.111 & -0.612 & 1 \\
\hline
\end{tabular}

*: Correlation is significant at the 0.01 level.

\subsection{Spatial Distribution (GIS based spatial mapping)}

GIS is frequently used in water resources management and provides fast and practical, decision making (Babiker et al. 2007; Ozelkan \& Karaman 2018). The spatial distribution maps of the irrigation water quality parameters (EC, TH, SAR, RSC, RSBC, and MR) are prepared using the Spatial Analyst Extension and "spline interpolation with barriers" techniques of ArcGIS (version 10.2.2) (Figure 5). Parameters such as EC, TDS, TH, RSC, and RSBC comply with irrigation water standard values in all sources in the basin. However, it is relatively higher in urbanization and agricultural areas.

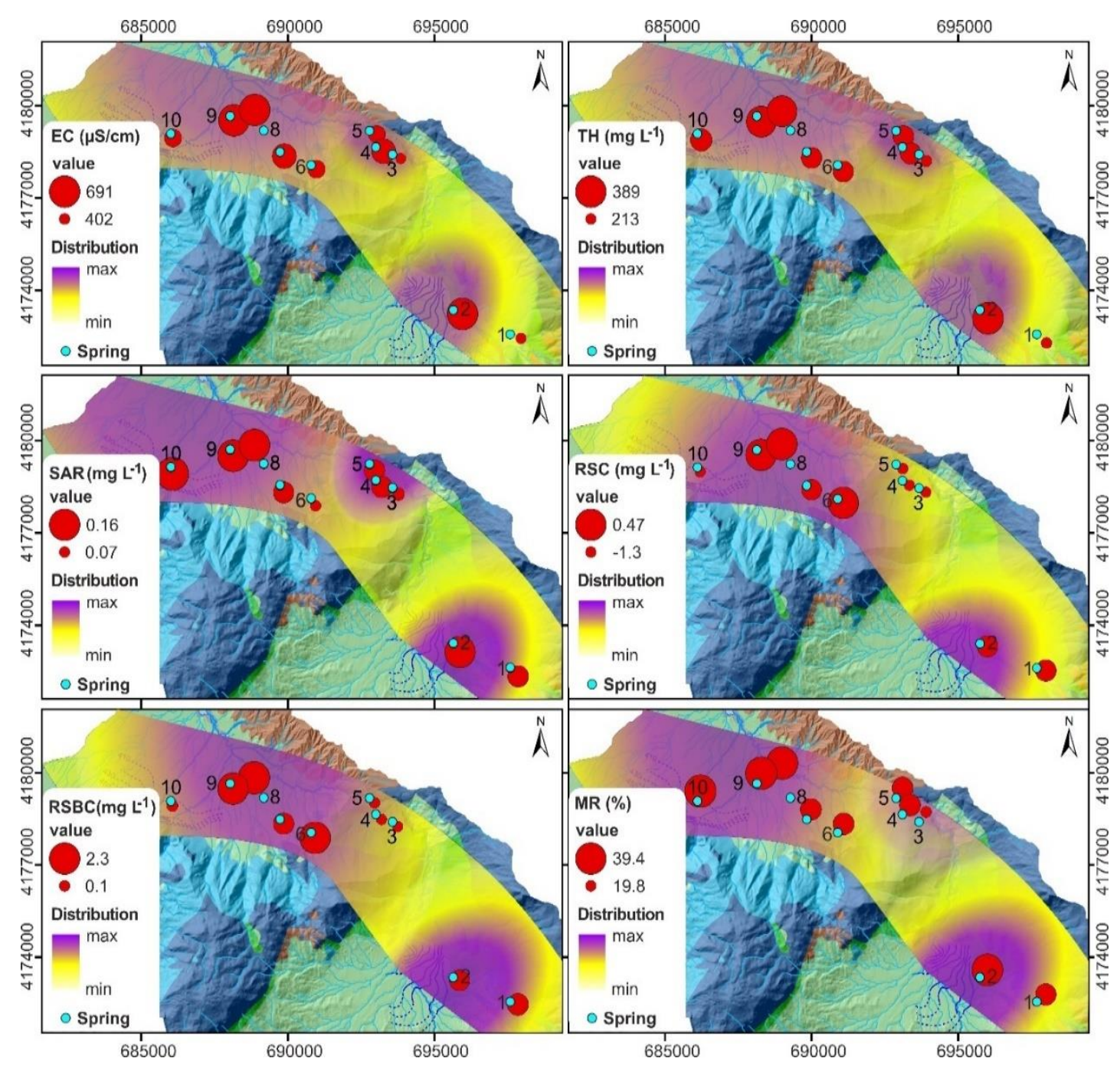

Figure 5- Spatial distribution maps of irrigation water quality of spring waters 


\section{Conclusions}

Spring waters are characterized as fresh type, good quality, alkaline in nature, and hard-very hard based on TDS, EC, $\mathrm{pH}$, and TH respectively. Generally, the domination of major ions is in the order of $\mathrm{Ca}^{2+}>\mathrm{Mg}^{2+}>\mathrm{Na}^{+}>\mathrm{K}^{+}>\mathrm{F}_{\text {for }}$ cations and $\mathrm{HCO}_{3}^{-}>$ $\mathrm{SO}_{4}{ }^{2-}>\mathrm{Cl}^{-}>\mathrm{NO}_{3}{ }^{-}$for anions. Gibbs plot specifies that all the basin spring waters' chemical evolution is mainly controlled by the "rock dominance" process. The major hydro-geochemical facies of waters were $\mathrm{Ca}^{2+}-\mathrm{Mg}^{2+}-\mathrm{HCO}_{3}{ }^{-}$water type. Alkaline earth metals $\left(\mathrm{Ca}^{2+}, \mathrm{Mg}^{2+}\right)$ and weak acid $\left(\mathrm{CO}_{3}{ }^{2-}, \mathrm{HCO}_{3}{ }^{-}\right)$dominates over the alkalies $\left(\mathrm{Na}^{+}, \mathrm{K}^{+}\right)$and strong acid $\left(\mathrm{Cl}^{-}, \mathrm{SO}_{4}{ }^{2-}\right)$ in all spring waters, respectively. According to Wilcox (1955) and USSL (Richards, 1954), all of the spring waters are "excellent to good" categories for irrigation and they can be used to irrigate all types of soils with little danger of exchangeable sodium (C2-S1). Concentration levels of bicarbonate, carbonate, magnesium, and sodium in all spring waters are suitable for irrigation based on RSC, RSBC, MR, SAR, \%Na classification. Consequently, the hydrogeochemical analysis of investigation in the study area displayed that concentrations of the major ions and values of important hydrochemical parameters were within the permissible limits for irrigation. The major influence on the chemistry of the basin groundwaters is naturally occurring processes carbonate, silicate, and evaporites weathering. The largest freshwater resources in the region are the aquifers in the Mesozoic marine carbonates of the pre-Neogene basement rocks. The results of this study provide valuable hydrogeochemical information on irrigation water characteristics of resources but need further data to precisely identify hydrogeological processes. Detailed hydrogeological studies including groundwater and surface water hydrogeochemical surveys will be useful for the protection and sustainable management of all water resources in the area. The results obtained in this paper can be a helpful guide to take the first step in such initiatives in the study area.

\section{Acknowledgments}

The author would like to thank the General Directorate of Water and Sewerage Administration of Denizli Metropolitan Municipality for allowing this article to be published.

\section{References}

Ako A A, Jun S, Takahiro H, Makoto K, Akoachere R A, George E N, Gloria E T E \& Alain L F T (2012). Spring water quality and usability in the Mount Cameroon area revealed by hydrogeochemistry. Environ Geochem Health 34:615-639 https://doi.org/10.1007/s10653-0129453-3

Andrade E, Palacio H A Q, Souza I H, Leao R A \& Guerreio M J (2008). Land Use Effects in Groundwater Composition of an Alluvial Aquifer by Multivariate Techniques. Environmental Research 106: 170-177

Appelo C A J \& Postma D (2005). Geochemistry, Groundwater and Pollution. $2^{\text {nd }}$ Edition, Balkema, Rotterdam https://doi.org/10.1201/9781439833544

Ayers R S \& Westcot D W (1985). Water Quality for Agriculture. FAO Irrigation and Drainage Paper 29 (revised 1), FAO, Rome, 174 pp

Babiker I S, Mohamed M A A \& Hiyama T (2007). Assessing groundwater quality using GIS. Water Resources Management 21(2007): 699715 https://doi.org/10.1007/s11269-006-9059-6

Batool A, Samad N, Kazmi S S, Ghufran M A, Imad S, Shafqat M \& Mahmood T (2018) Spring water quality and human health: an assessment of natural springs of margalla hills Islamabad zone-III. Int J Hydrol 2:41-46 https://doi.org/10.15406/ijh.2018.02.00049

Bhandari N S \& Joshi H K (2013) Quality of spring water for irrigation in the Almora district of Uttarakhand, India. Chin J Geochem 32:130-136 https://doi.org/10.1007/s13201-014-0213-7

Bozkurt E (2003). Origin of NE-trending basins in western Turkey. Geodinamica Acta 16: 61-81. https://doi.org/10.1016/S0985-3111(03)00002-0

Catroll D (1962). Rain water as a chemical agent of geological process: A view. USGS water supply 1533: 18-20

Chadha D K (1999). A proposed new diagram for geochemical classification of natural waters and interpretation of chemical data. Hydrogeology Journal 7(5): 431-439 https://doi.org/10.1007/s100400050216

Dinka M O, Loiskandl W \& Ndambuki J M (2015). Hydrochemical characterization of various surface water and groundwater resources available in Matahara areas, Fantella region of Oromiya region. Journal of Hydrology: Regional Studies 3: 444-456 https://doi.org/10.1016/j.ejrh.2015.02.007

Doneen L D (1962). The influence of crop and soil on percolating water. In Proceedings of the biennial conference on ground water recharge (pp. 156-163)

Eaton F M (1950). Significance of carbonates in irrigation waters. Soil Science. 69: 123-134

Edmunds W M \& Shand P (2009). Groundwater baseline quality W.M. Edmunds, P. Shand (Eds.), Natural Groundwater Quality, Blackwell Publishing Ltd., Oxford, pp. 1-21 https://doi.org/10.1002/9781444300345.fmatter

Freeze R A \& Cherry J A (1979). Groundwater: Englewood Cliffs. New Jersey

Gibbs R J (1970). Mechanisms controlling world water chemistry Science. 170: 1088-1090

Kamtchueng B T, Fantong W Y, Wirmvem M J, Tiodjio R E, Takounjou A F, Ndam Ngoupayou J R, Kusakabe M, Zhang J, Ohba T, Tanyileke G, Hell J V \& Ueda A (2016). Hydrogeochemistry and quality of surface water and groundwater in the vicinity of Lake Monoun, West Cameroon: approach from multivariate statistical analysis and stable isotopic characterization Environ. Monit. Assess., 188 p. 524 https://doi.org/10.1007/s10661-016-5514-x

Kocyigit A (2005). The Denizli graben-horst system and the eastern limit of western Anatolian continental extension: basin fill, structure, deformational mode, throw amount and episodic evolutionary history, SW Turkey Geodinamica Acta 18(3-4): 167-208 https://doi.org/10.3166/ga.18.167-208

Kumar S K, Rammohan V, Sahayam J D \& Jeevanandam M (2009). Assessment of groundwater quality and hydrogeochemistry of Manimuktha River basin, Tamil Nadu, India. Environ Monit Assess (2009) 159: 341-351 https://doi.org/10.1007/s10661-008-0633-7

Meybeck M \& Helmer R (1996). An introduction to water quality. Water Quality assessments. $2^{\text {nd }}$ ed. Taylor Fr. New York 122

MTA (2018). GeoScience Map Viewer and Drawing Editor [WWW Document]. URL http://yerbilimleri.mta.gov.tr/anasayfa.aspx

Nagaraju A, Kumar K S \& Thejaswi A (2014). Assessment of groundwater quality for irrigation: a case study from Bandalamottu lead mining area, Guntur District, Andhra Pradesh, South India. Application Water Science 4: 385-396 https://doi.org/10.1007/s13201-014-0154-1 
Nair H C, Padmalal D, Joseph A \& Vinod P G (2015). Hydrochemical assessment of tropical springs - a case study from SW India Environ. Monit. Assess, 187(2): 1-24 https://doi.org/ 10.1007/s10661-014-4164-0

Okay A I (1989) Geology of the Menderes massif and the Lycian nappes south of Denizli, Western Taurides. Mineral Research Exploration Bulletin 109(1989): 37-51

Ozelkan E \& Karaman M (2018). Hydrometeorological Evaluation of Urban Areas in GIS Environment, in: Health, A. (Ed.), Changing and Developing Laspeki Urban Infrastructure (In Turkish). Çanakkale Onsekiz Mart University, Ankara, pp. 97-109

Piper A M (1944). A graphical procedure in the geochemical interpretation of water analyses: Geophysical Union Transactions. v. 25

Raghunath H M (1987). Groundwater, $2^{\text {nd }}$ ed. Wiley Eastern Ltd, New Delhi

Raju N J (2007). Hydrogeochemical parameters for assessment of groundwater quality in the upper Gunjanaeru River basin, Cuddapah District, Andhra Pradesh, South India, Environmental Geology 52: 1067-1074

Richards L A (1954). Diagnosis and improvement of saline and alkali soils. Handbook No. 60. US Department of Agriculture. Washington, DC

Richards L A (1969). Diagnosis and improvement of saline and alkali soils. United States Department of Agriculture. Washington

Roy K, Ansari M S, Karim M R, Das R, Mallick B \& Gain A K (2015). Irrigation water quality assessment and identification of river pollution sources in Bangladesh: Implications in policy and management. J Water Resour Hydro Eng 4: 303-317

Sawyer C N \& McCarty P L (1967). Chemistry for sanitary engineers. In: Chemistry for sanitary engineers, $2^{\text {nd }}$ edn. McGraw-Hill, New York, p 518

Szabolcs I \& Darab C (1964). The influence of irrigation water of high sodium carbonate content of soils, in: Proceedings of $8^{\text {th }}$ International Congress of ISSS, Trans II. pp. 803-812

Taşdelen S, Çelik S B \& Akyol E (2016). Geological and Geotechnical Properties of Irgilli Town (Denizli), Pamukkale Üniversitesi Mühendislik Bilimleri Dergisi 22(3): 213-219 https://doi: 10.5505/pajes.2015.30932.

Taşdelen S (2018). Hydrogeological and Geophysical Characterization of Kozlupınar and Bentpınarı Water Springs (Denizli, SW Turkey). IJRDO-Journal Application Science. 4.

Taşdelen S, Akyol E, Aydın A \& Kaya A (2017). Relation Between Hydrodynamics of Gokpinar Springs and Fault Zones Denizli-Turkey, International Journal of Advances in Science, Engineering and Technology 5,3 (Spcl Iss-1): 68-73

Tiwari R N (2011). Assessment of groundwater quality and pollution potential of Jawa block Rewa district, Madhya Pradesh, India. Proceedings of the International Academy of Ecology and Environmental Sciences 1(3-4): 202-212

Westaway R (1993) Neogene evolution of the Denizli region of western Turkey. Structural Geology 15(37-53): 1993 https://doi.org/10.1016/01918141(93)90077-N

Wilcox L V (1955). Classification and use of Irrigation waters, U.S. Geological Department Agricultural Arc 969, 19. Washington DC

(C) 2021 by the authors. Licensee Ankara University, Faculty of Agriculture, Ankara, Turkey. This article is an open access article distributed under the terms and conditions of the Creative Commons Attribution (CC BY) license (http://creativecommons.org/licenses/by/4.0/). 